\title{
APLIKASI DAN DIFERENSIASI PENDIDIKAN ISLAM
}

\author{
Muhammad Hifdil Islam
}

\begin{abstract}
Abstrak; This article explores the use of several Islamic terms, and provides guidance to clarify their use in internal and external discourse. This article describes the typology of Islamic education and the institutions associated with it. It aims to increase understanding of important conceptual differences that depend on subtle language variations such as the differences between Muslim and Muslim education, and between teaching Islam and teaching about Islam. This article then attempts to explain the theoretical conception of "Islamic education," which considers scripture and the prophetic statement of Islam, along with the commonly beld approach to education in Muslim history. This article concludes that the main motivations and characteristics of a bolistic and directed education program are divided between Islamic and Western traditions, a phenomenon partly explained by transmission and cumulative divided educational values from classical times to the present.
\end{abstract}

\section{PENGANTAR}

Pengaruh politik, ekonomi, dan sosial dari globalisasi sangat lah beragam, tetapi tentu saja ini merupakan indikasi upaya kita sebagai manusia untuk mendefinisikan dan memahami tempat kita di dunia. Karena wilayah dan budaya bersentuhan satu sama lain, seringkali sulit bagi orang untuk mengenali gagasan, nilai, dan lembaga paralel dalam masyarakat lain. Jauh lebih mudah untuk mengenali perbedaan dan membayangkan bahwa mereka mewakili jarak yang tidak dapat dijembatani dari apa yang akrab. Meskipun tren menuju interdependensi

\footnotetext{
* Dosen Tetap Fakultas Tarbiyah Inzah Genggong Kraksaan
} 
global, perbedaan yang tak dapat ditunda terus digarisbawahi antara daerah dan kelompok melalui penggunaan penanda yang menciptakan jarak. "Islami" adalah istilah yang telah digunakan sebagai salah satu penanda tersebut. Secara khusus, kata itu sering disajikan sebagai kata sifat dalam percakapan sehari-hari yang dengan rapi memisahkan katakata akrab dari normal dan mengubahnya menjadi konsep-konsep asing yang tidak dapat dijangkau.

Dalam wacana tentang Islam dan Muslim di Indonesia, Eropa, Timur tengah, Amerika dan di belahan negara lainnya, istilah, Islam, melekat pada berbagai fenomena. Umat Muslim menggunakan istilah ini untuk merujuk pada apa yang berhubungan dengan ajaran atau institusi Islam, tetapi Muslim dan non-Muslim juga sering menggunakan kata sifat "Islam", untuk meningkatkan ekspresi budaya ke posisi institusi atau praktik normatif atau sempurna. Penggunaan istilah yang bernuansa buruk, Islam, di antara komentator publik sering gagal membuat perbedaan antara apa yang berkaitan langsung dengan Islam dan doktrinnya, dan tindakan yang dilakukan pengikutnya di bidang budaya atau sosial. Dengan demikian istilah yang digunakan untuk menandakan Islam dan Muslim kurang presisi ketika digunakan oleh Muslim dan orang lain dalam wacana publik.

Untuk mencegah kesalahpahaman yang bisa mengarah pada mischaracterization dan bahkan demonization Muslim, istilah-istilah ini perlu dieksplorasi dan diklarifikasi. Setelah serangan 11 September 2001, wacana publik di berbagai negara barat khususnya di Amerika Serikat tentang Islam secara khusus menonjol, yang ditujukan untuk meningkatkan pemahaman, atau menuju penghapusan asosiasi positif dengan agama dunia yang didukung oleh sekitar seperlima dari umat manusia, termasuk setidaknya lima juta orang Amerika. Spekulasi dan kebijakan oleh para pakar dan politisi telah menargetkan "Pendidikan Islam" sebagai "penyebab" yang mungkin dari apa yang disebut "Radikalisme Islam” atau "Terorisme Islam." Dengan demikian, berbagai rekomendasi dan langkah-langkah telah direnungkan untuk mereformasi Pendidikan Islam di Amerika Serikat dan belahan negara barat lainnya. Paling tidak, diskusi publik harus membangun landasan keakuratan dan wacana yang berbeda, karena upaya untuk mereformasi apa yang kurang dipahami pasti akan gagal atau bahkan menjadi bumerang. 
Berfokus pada konteks penggunaan istilah Islam, tujuan artikel ini adalah 1) untuk mengeksplorasi terminologi yang terkait dengan Islam dan memberikan panduan untuk memperjelas penggunaannya dalam wacana internal dan eksternal; 2) untuk menyusun tipologi ekspresi pendidikan Islam di berbagai institusi; 3) untuk mengembangkan definisi yang lebih akurat yang dapat membantu menjembatani perbedaan antara wacana publik tentang pendidikan Islam di kalangan orang barat dan di antara kaum Muslim; dan 4) untuk menerangkan konsep-konsep pendidikan yang terkait dengan Islam dan tradisi pendidikan Muslim dan untuk mengidentifikasi paralel dengan konsep yang juga dikaitkan dengan nilai-nilai pendidikan dan budaya Barat.

\section{MEMBEDAH TERMA ISLAM DALAM PERSPEKTIF NEGARA BARAT}

Masalah umum dengan materi informatif yang berkaitan dengan Islam adalah penggunaan terminologi yang salah atau tidak konsisten, khususnya penggunaan Islam sebagai nama agama, Islam sebagai kata sifat, dan Muslim sebagai kata benda atau kata sifat.

Islam adalah nama agama, yang nabi pertamanya adalah Adam, dan yang nabi terakhirnya adalah Muhammad; itu berarti keadaan damai yang dicapai melalui penyerahan diri kepada Tuhan. Muslim digunakan untuk penganut agama Islam. Para penulis dan komentator telah menciptakan banyak kesalahpahaman dengan membingungkan ekspresi kata sifat mengenai Islam. Istilah Islam secara akurat diterapkan hanya untuk yang berkaitan langsung dengan iman dan doktrin-doktrinnya (seperti nilai-nilai Islam, prinsip dan kepercayaan, ibadah Islam, hukum Islam). Istilah Islam mengkonotasikan agama sebagai cita-cita. Sumber inti Islam dari Qur'an dan Sunnah (kata-kata dan perbuatan Muhammad yang ditransmisikan melalui literatur Hadits) memberikan pengetahuan tentang dunia ini. Seseorang dapat memeriksa konstruksi iman, menafsirkan ajaran dan praktiknya; Namun, orang tidak boleh menggambarkan seseorang atau fenomena historis apa pun sebagai Islam. Untuk menggambarkan masalah dalam penggunaan, pertimbangkan formulasi yang tampaknya jinak seperti "Wanita Islam," "Populasi Islam," atau "Negara-Negara Islam," Ketika fenomena sejarah dan praktik budaya menyimpang dari ajaran 
agama, menunjuk sesuatu sebagai Islami menjadi sangat bermasalah. Melakukan hal itu mendorong gagasan kaum Muslim sebagai kelompok monolitik dan homogen yang bertindak murni dalam istilah agama. Ini juga menutupi perbedaan budaya dan sosial, dan menghalangi pengaruh sekuler dan historis. Paling buruknya, konstruksi kata sifat yang keliru seperti itu menghasilkan oxymorons seperti "Teroris Islam" dan "Ekstrimis Islam," berbeda dengan definisi dasar Islam, ketentuan Hukum Islam terhadap kekerasan tak terduga dan ekstremisme dalam interpretasi agama, dan cita-cita umum dari Muslim. ${ }^{1}$

Solusi paling sederhana adalah dengan menggunakan Islam dan Islam semata-mata untuk apa yang berkaitan dengan agama, dan menggunakan Muslim secara bijaksana sebagai kata sifat untuk menunjukkan karya dan tindakan umat Islam dan lembaga-lembaganya (seperti populasi Muslim, pemerintah Muslim, negara atau peradaban, seni Muslim). Penggunaan istilah ini, Muslim, bagaimanapun, mengesampingkan peran penting yang dimainkan oleh banyak non-Muslim yang tinggal di negara-negara mayoritas Muslim hingga saat ini, dan juga mengabaikan gerakan politik dan budaya yang diakui sekuler dalam dorongan, dan menunjuk mereka dengan nama agama mayoritas. Adapun penggunaan kasar penanda, “ekstremis Muslim” lebih disukai daripada ekstremis Islam, karena itu mencerminkan setidaknya identifikasi diri oleh orang yang dijelaskan, tetapi tidak memfitnah agama pada tingkat yang sama. Ekstremisme bukanlah atribut yang benar-benar Muslim, karena Islam menentukan moderasi dalam segala hal. ${ }^{2}$

1 Sahih al-Bukhari, vol. 7, hadis 577, dikutip dalam The Alim for Windows, rilis 4,5, Silver Spring, MD: ISL Software. Di antara banyak sumber lain, ekstremisme dikutuk dalam Islam, seperti yang disampaikan Nabi Muhammad dalam hadistnya, “...bersikaplah moderat dalam perbuatan religious-Mu dan lakukanlah perbuatan yang sesuai dengan kemampuan kamu: dan tidak ada di antara kamu yang menginginkan kematian, karena jika ia adalah pelaku yang baik , dia dapat meningkatkan perbuatan baiknya, dan jika dia adalah pelaku kejahatan, dia mungkin bertobat kepada Tuhan."

2 Sebagai contoh, Al-Quran mencirikan komunitas Muslim sebagai mengikuti jalan moderat dalam Surat Al Baqarah ayat 142-143: “... Katakanlah: Kepunyaan Allah adalah Timur dan Barat. Dia membimbing siapa yang Dia kehendaki untuk menempuh jalan yang lurus. membuat dari Anda sebuah komunitas orang-orang beriman adil seimbang bahwa kamu mungkin menjadi saksi atas bangsa-bangsa dan Nabi menjadi saksi atas Anda ... “ 
Memahami istilah ini, Muslim, sebagai sebuah aspirasi untuk mencapai perdamaian melalui penyerahan diri kepada Tuhan berarti bahwa dengan definisi ketika seseorang melanggar ajaran Islam yang jelas dan telah meninggalkan penyerahan diri kepada Tuhan. Di dalam pandangan islam, tingkat keimanan di sisi Tuhan tidak dapat ditentukan secara kasat mata, apakha seseorang tersebut dikatakan saleh atau tidak, Ketika umat Islam mengutuk terorisme berdasarkan pada ajaran Islam yang jelas tentang kesucian Islam kehidupan manusia dan kekebalan warga sipil tak bersenjata dari pertempuran, mereka menegaskan pengucilan tindakan semacam itu dari ranah perilaku yang disetujui, atau Islami. Tindakan semacam itu tidak Islami; mereka melanggar kewajiban untuk menaati ajaran Tuhan. ${ }^{3}$

Menurut ajaran Islam, penentu akhir makna adalah Tuhan, dan setiap interpretasi Islam oleh manusia tentu tidak sempurna. ${ }^{4}$ Orang, artefak budaya, dan institusi dapat diturunkan dari dan diinformasikan oleh ajaran Islam sampai tingkat tertentu, tetapi pengaruh budaya dan ideologis mungkin atau mungkin tidak sejalan dengan prinsip-prinsip Islam, dan mungkin sering bertentangan dengan mereka. Singkatnya, tindakan dan konstruksi manusia gagal menjadi murni Islami, dan karena itu tidak boleh dilambangkan seperti itu.

\section{TIPOLOGI PENDIDIKAN ISLAM}

Istilah umum, pendidikan Islam, dapat berarti banyak hal. Oleh karena itu, perlu untuk membedakan antara beragam institusi yang terlibat dalam pendidikan yang terkait dengan Islam. Untuk mencapai presisi tertentu, sebuah preposisi harus digunakan untuk membuat frasa yang bermakna menggambarkan jenis kegiatan pendidikan dan

3 Ezzedin Ibrahim dan Denys Johnson-Davies, Terjemahan., Hadits Empat Puluh An-Nawawi (Beirut: Dar al-Qur'an al-Kareem, 1976). Misalnya, pada hal. 106-107, sebuah hadits yang mengemukakan prinsip yudisial adalah, "Seharusnya tidak ada yang merugikan atau membalas kerugian.” Pada p. 42-43: “... dia yang menghindari hal-hal yang meragukan dalam membersihkan dirinya sendiri sehubungan dengan agamanya dan kehormatannya, tetapi dia yang jatuh ke dalam hal-hal yang meragukan jatuh ke dalam hal-hal yang melanggar hukum ...”.

4 "Dialah yang telah menyatakan kepadamu Kitab Suci di mana adalah wahyu yang jelas ...Tidak ada yang tahu penjelasannya kecuali Allah ..." (Al-Qur'an-3: 7). 
tujuannya. Kemudian, elemen-elemen tipologi muncul, memberi cahaya pada lembaga-lembaga yang melaksanakan bentuk-bentuk pendidikan dan tujuan dari setiap upaya. Singkatnya, kita dapat mengidentifikasi empat jenis kegiatan pendidikan: pendidikan Muslim dalam iman Islam mereka; pendidikan bagi umat Islam yang mencakup disiplin agama dan sekuler; pendidikan tentang Islam bagi mereka yang bukan Muslim; dan pendidikan dalam semangat dan tradisi Islam. Bagian berikut menjelaskan tiga jenis kegiatan dan institusi pendidikan yang sedang berlangsung di beberapa negara barat seperti amerika serikat dan beberap negara di Eropa, sementara tipe keempat menyinari beberapa konsep tradisional pendidikan Islam.

\section{Pendidikan Islam di Organisasi Islam}

Dalam arti yang paling harfiah, pendidikan Islam dapat merujuk pada upaya komunitas Muslim untuk mendidiknya sendiri, untuk mewariskan warisan pengetahuan Islam, pertama dan terutama melalui sumber-sumber utamanya, Al-Qur'an dan Sunnah. Pendidikan Muslim ini mungkin terjadi di masjid, sekolah atau universitas, dan organisasi lain yang didirikan oleh Muslim selama berabad-abad. Khusus di Amerika Serikat, anak lakilaki dan perempuan dan laki-laki dewasa dan perempuan dilayani oleh jenis pendidikan Islam ini. ${ }^{5}$ Sementara pendidikan tersebut mengambil Islam sebagai subjeknya, itu mungkin tidak cukup berlabel "Islami," karena upaya Muslim mungkin gagal memenuhi cita-cita dan prinsipprinsip Islam. Misalnya, beberapa institusi dapat mengajarkan interaksi konstruktif komunitas Muslim minoritas dengan komunitas agama lain, sementara yang lain mempraktekkan posisi yang lebih isolasionis. Secara historis, orang mungkin menjelaskan posisi di sepanjang spektrum ini

5 Distribusi gender di antara peserta dalam program sekolah akhir pekan umumnya seimbang, dan distribusi etnis biasanya mencerminkan komposisi masyarakat setempat. Pernyataan-pernyataan ini didasarkan pada pengalaman yang diamati secara luas. Anak laki-laki dan perempuan menghadiri sekolah akhir pekan di masjid karena mereka menghadiri sekolah umum di mana tidak ada pengajaran agama. Tidak ada kelompok Muslim yang mengklaim sekolah akhir pekan itu jumlah hadirin sebagian besar laki-laki, seolah-olah bias terhadap pendidikan perempuan mencegah Muslim mengirim anak perempuan mereka untuk belajar Alquran dan doa. 
dengan mempelajari tingkat tekanan dari masyarakat sekitarnya, seperti penindasan agama di bawah dominasi Soviet, akibat dari Reconquista pada populasi Morisco di Spanyol, atau kehidupan beragama minoritas di bawah jaminan konstitusi amandemen pertama Amerika Serikat. Dalam konteks Amerika, imigran Muslim baru-baru ini mungkin berbeda dari generasi kedua atau generasi ketiga Muslim Amerika atau orang Amerika asli "pribumi" dalam upaya pendidikan mereka.

Secara umum, upaya ini dapat lebih tepat dikategorikan sebagai "pendidikan Muslim." Penelitian terbaru oleh umat Islam Georgetown University dalam proyek American Public Square, Theologia The Seminari Mosque Survey, dan Dewan Hubungan Islam Amerika menunjukkan bahwa setidaknya ada 1209 masjid di Amerika Serikat, hampir semuanya menyediakan program pengajaran agama untuk orang dewasa dan / atau anak-anak, dan $20 \%$ dari masjid dikaitkan dengan atau mensponsori sekolah penuh waktu. ${ }^{6}$ Banyak masjid mengadakan sekolah Sabtu, lingkaran belajar akhir pekan, dan program sepulang sekolah. Waktu instruksional yang tersedia membatasi program-program ini ke dasar beberapa orang akan mengatakan minimum yang diperlukan untuk memungkinkan siswa untuk memahami prinsip-prinsip Islam dan mampu melaksanakan praktik inti dari Rukun Iman dan Rukun Islam. Programprogram semacam itu mengajarkan Al-Quran, makna dan pembacaannya, keyakinan dan praktik Islam, dan setidaknya tingkat bahasa Arab minimal untuk ibadah. Beberapa program semacam itu lebih berhasil dalam memperkuat pentingnya keluarga dalam transmisi budaya dan dukungan sosial bagi para anggota agama ${ }^{7}$. Dalam tujuan dan kegiatan mereka, program masjid umumnya sesuai dengan instruksi keagamaan akhir pekan yang dilakukan di gereja-gereja Amerika, sinagog, dan kuil.

${ }^{6}$ Bagby, I., Perl, P., \& Froehle, B. (2001). The mosque in America : A national portrait. Washington, DC : Council on American-Islamic Relations. Haddad, Y. (1997, March). Islam in the United States : A tentative ascent; A conversation. U.S. Society and Values: The religious landscape of the United States. Khalidi, O. (2000). Mosque. In W. C. Roof (Ed.), Contemporary American religion. New York : Macmillan.

7 Ismail, M. (n.d.). Teaching tips and effective strategies for weekend Islamic schools. Indianapolis, IN: American Trust Publications. Islamic Schools League. Available at: http://www.4islamicschools.org. (2003) 


\section{Pendidikan Islam di Sekolah Muslim}

Sekolah Muslim penuh waktu mengisi kategori pendidikan untuk Muslim, karena mereka merangkul perusahaan yang jauh lebih luas daripada ceramah masjid, program setelah sekolah, dan sekolah akhir pekan. Lembaga-lembaga ini sering digambarkan oleh Muslim sebagai sekolah Islam di mana pendidik memberikan pendidikan "sekuler" dan Islam. Lebih tepatnya, lembaga-lembaga ini dapat dianggap sekolahsekolah Muslim, yang menunjukkan tujuan untuk hidup sesuai dengan standar Islam, daripada menyiratkan pencapaiannya. Banyak sekolah Muslim memiliki nama (sering dalam bahasa Arab) yang membangkitkan cita-cita dan aspirasi, seperti "Cahaya" (al-Nur), "Iman" (al-Iman) dan "Panduan" (al-Huda), atau nama-nama tokoh terkenal dalam sejarah Muslim. Saat ini ada setidaknya 112 sekolah Muslim yang menyediakan sekolah dasar, dasar, menengah dan / atau menengah untuk anak-anak Muslim di Amerika Serikat (Liga Sekolah Islam, 2004). Beberapa anak non-Muslim juga menghadiri inilembaga, dan karena beberapa sekolah memperoleh reputasi untuk keunggulan pendidikan, jumlah mereka kemungkinan akan bertambah. Mayoritas sekolah-sekolah Muslim melayani kelas-kelas dasar K-6, tetapi banyak sekolah K-8 dan beberapa sekolah menengah ada. Selain lembaga-lembaga ini, semakin banyak orang tua Muslim yang mendidik anak-anak mereka, seperti rekan-rekan mereka di komunitas agama dan bahkan sekuler lainnya di AS hari ini. ${ }^{8}$

Untuk mengevaluasi apa pendidikan Islam bagi umat Islam berarti, perlu untuk memahami kurikulum di sekolah-sekolah seperti itu. Untuk memenuhi tuntutan orang tua yang membayar uang sekolah, sekolah penuh waktu Muslim umumnya cukup dekat dengan kurikulum sekolah negeri dan negara bagian setempat. Dalam mata pelajaran akademik inti, buku teks yang diproduksi secara komersial untuk sekolah umum digunakan di ruang kelas sekolah Muslim. Untuk program-program standar ini dalam mata pelajaran inti, mereka menambahkan instruksi dalam pembacaan dan hafalan Al-Qur'an, keyakinan dan praktik dasar Islam, dan biasanya bahasa Arab (tapi kadang-kadang Urdu atau Farsi). Dalam mata pelajaran ini, baik kurikulum maupun buku teks tidak

${ }^{8}$ Muslim Home School Network and Resource. Available at: http://www. muslimhomeschool.com/index.html, 2004 
distandarisasi. Sebaliknya, sementara studi formal belum dipersiapkan, lebih dari dua puluh tahun diskusi di antara para pendidik Muslim yang bekerja di berbagai jenis sekolah menunjukkan bahwa mencapai standardisasi adalah salah satu tantangan instruksional terbesar mereka. Hal ini diperparah oleh fakta bahwa materi kurikulum yang berkaitan dengan pengajaran tentang Islam yang diproduksi di luar negeri - bahkan untuk studi bahasa Arab - dipandang sebagai tidak relevan atau tidak cocok untuk kehidupan dan budaya siswa muda di Amerika Serikat dan Eropa $^{9}$ (Tauhidi, 2001; Safi, 1999). Dalam mengajarkan Al-Qur'an, misalnya, banyak sekolah Muslim Amerika Serikat semakin menekankan bahwa siswa belajar arti ayat-ayat dalam terjemahan dan alasan di balik praktik-praktik Islam, daripada hanya mengingat kata-kata dan praktik dalam bahasa Arab tanpa memperhatikan pemahaman. Para siswa juga cenderung untuk mendapatkan rentang pendapat yang lebih banyak mengenai rincian praktik Islam berdasarkan beasiswa di beberapa sekolah hukum Islam, tidak seperti di kebanyakan negara di mana satu sekolah hukum tertentu mendominasi di kalangan Muslim. Pendidik Muslim di Amerika Serikat secara luas percaya bahwa, agar pemuda dapat hidup sebagai Muslim dalam masyarakat bebas yang menempatkan sedikit kendala luar pada perilaku individu, siswa harus benar-benar memahami dan menginternalisasi prinsip-prinsip, keyakinan dan praktik Islam, dan belajar bagaimana menerapkannya. dalam masyarakat kontemporer. Seperti sekolah paroki lainnya dalam tradisi sekolah swasta Amerika, sekolah-sekolah Muslim yang melaksanakan pendidikan bagi umat Islam berusaha untuk mencapai keunggulan pendidikan, tetapi juga untuk mengintegrasikan nilai-nilai agama ke dalam pengajaran lintas kurikulum dan melalui pembelajaran layanan dalam keluarga, sekolah dan masyarakat.

\section{PENDIDIKAN TENTANG ISLAM MELALUI SEKOLAH}

Pendidikan tentang Islam di buku pelajaran sekolah Amerika telah berkembang selama dua setengah dekade terakhir. Buku pelajaran dan

9 Safi, L. (1999). The transforming experience of American Muslims: Islamic education and political maturation. Available at: http://home.att.net/ louaysafi/ articles/1999/am-muslims.html. Tauhidi, Daud. The Tarbiyah Project: An Overview. Daud Tauhidi, 2001. 
kurikulum Peradaban Barat yang digunakan untuk mengajarkan versi awal "sejarah dunia" di sekolah-sekolah sering membatasi peliputan Islam sebagai latar belakang informasi tentang peristiwa-peristiwa dalam sejarah Eropa, seperti Perang Salib, jatuhnya Konstantinopel, atau Reconquista. Akun-akun masyarakat Muslim modern selalu berada di bawah rubrik Timur Tengah, dan hampir secara eksklusif digambarkan dalam liputan masalah Arab Israel. Di luar itu, siswa menerima sedikit lebih dari pandangan sepintas pada lanskap gurun dan liputan masyarakat Muslim menempatkan Islam di pusat dikotomi tradisional / modern (yaitu hanya masyarakat yang mengikuti kursus perkembangan Barat yang “modern"). Bab-bab awal buku teks penuh dengan ketidakakuratan dan ketidakkonsistenan, dan menunjukkan kecenderungan untuk mengambil penjelasan orientalis barat tentang Islam dan sejarah serta masyarakat Muslim pada nilai nominalnya, jauh setelah akademisi akademis Islam telah bergerak melampaui anggapan-anggapan ini. Keterlambatan dalam menerapkan beasiswa kontemporer pada penulisan buku teks sejarah dunia secara serius menghambat peliputan Islam dan Muslim karena liputan tersebut mulai dimasukkan dalam bagian akhir. 1980-an. Namun, upaya selama dekade terakhir telah menghasilkan peningkatan yang cukup besar. ${ }^{10}$

Selama dua dekade, pengajaran tentang agama-agama dunia telah menjadi bagian dari kurikulum sekolah umum, yang paling menonjol dalam studi sosial. Reformasi kurikulum dalam sejarah membantu mengembalikan tempat pengajaran tentang agama dalam studi Amerika Serikat., dan memperluas jangkauan agama-agama besar dunia, termasuk Islam, dalam kelas geografi dan sejarah dunia. Pada tahun 2000, Dewan Pendidikan Islam bersama-sama menerbitkan dengan Pusat Amandemen Pertama Forum Kebebasan studi Pengajaran tentang Agama dalam Standar Studi Sosial Nasional dan Negara. ${ }^{11}$ Hasil dari hampir satu dekade studi kurikulum, itu menelusuri pengembangan standar nasional dan negara di AS, menunjukkan inklusi luas studi tentang agama dan kesadaran kerangka kerja konstitusional yang mendukung inklusi ini.

${ }^{10}$ Douglass, S. L. \& Dunn, R. E. (2001). Interpreting Islam in American schools. In H. Donnan (Ed.), Interpreting Islam. London : Sage Publications. Hal. 76-98

${ }^{11}$ Douglass, S. L. (2000). Teaching about religion in national and state social studies standards. Fountain Valley, CA : Council on Islamic Education. 
Studi ini menyimpulkan bahwa pengajaran tentang agama diperlukan oleh dokumen standar negara yang baru dikembangkan, di berbagai tingkatan kelas. Faktor paling penting dalam mempromosikan pengajaran tentang agama di sekolah-sekolah umum adalah diseminasi pedoman Pusat Amandemen Pertama untuk pengajaran tentang agama secara konstitusional. ${ }^{12}$ Pedoman ini telah meningkatkan tingkat kenyamanan guru, meskipun pelatihan guru tidak konsisten dari satu sistem ke sistem dan negara bagian ke negara. Tuntutan hukum terbaru tentang pengajaran tentang Islam menggambarkan bahwa para guru belum tentu terbiasa dengan pedoman Pusat Amandemen Pertama. Padahal pedomannya sudah disebarluaskan kepada setiap kepala sekolah oleh Departemen Pendidikan A.S. di bawah pemerintahan Clinton, mereka mungkin tidak meninggalkan meja mereka atau mencapai guru yang akan mengimplementasikannya.

Ketaatan umum terhadap pedoman dan penerapannya dalam pengembangan buku teks telah melakukan lebih dari apa pun untuk meningkatkan akurasi penggambaran buku teks tentang keyakinan dan praktik dasar, kisah asal dan sejarah budaya dan kelembagaan berikutnya dari berbagai agama. Yang paling utama di antara perubahan ini adalah penggunaan frasa atributif yang konsisten, dikombinasikan dengan akurasi faktual yang lebih besar. Di masa lalu, para guru yang tidak nyaman dengan topik agama hanya akan menghilangkan topik itu dari rencana pelajaran mereka. Bersamaan dengan pedoman, penetapan standar negara untuk sejarah sebagai subjek inti telah membuat topik utama seperti agama-agama dunia wajib di sekolah-sekolah, terutama di mana pengujian akuntabilitas dipraktikkan. Bahkan di mana pun tidak, kurikulum telah mendapat manfaat dari kejelasan tambahan dalam hal apa yang harus dipelajari siswa. ${ }^{13}$

Mengikuti mandat kurikulum negara bagian yang ada di Amerika Serikat, yang sekarang sedang diuji di banyak negara, penerbit buku teks utama telah memasukkan konten tentang agama dalam buku-buku yang

${ }^{12}$ Haynes, C. C. \& Thomas, O. (2002). Finding common ground: A guide to religious liberty in public Schools. Nashville, TN : First Amendment Center.

${ }^{13}$ Douglass, S. L. (1998, Winter). God spoke: Guidelines and coverage of Abrahamic religions in world history textbooks. Religion and Education, 25 ( 1/2 ), $45-58$. 
mereka kirimkan untuk diadopsi ke sistem sekolah umum negara bagian. Dalam buku teks sejarah dan geografi dunia, Islam mengambil tempat di antara catatan sejarah semua agama besar dunia, termasuk Hindu, Budha, Yahudi, Kristen, Konfusianisme, Daoisme dan Shintoisme dan beberapa tradisi adat lainnya. Cakupan Islam meliputi kisah asal-usul, menampilkan kehidupan Muhammad dan pertumbuhan komunitas Muslim awal, suksesi politik dan penaklukan cepat setelah kematian Muhammad, dan pengembangan Peradaban Muslim hingga periode Ottoman. Kisah-kisah sejarah abad kedua puluh mencakup gerakan keagamaan, termasuk yang ada di masyarakat Muslim, dan cakupan Timur Tengah mencakup diskusi tentang peran agama dalam keluarga dan kehidupan sosial. ${ }^{14}$ Baik buku pelajaran dasar dan menengah untuk sejarah Amerika Serikat. sering menyebutkan keragaman populasi A.S., dan mungkin termasuk menyebutkan Muslim.

Cakupan Timur Tengah, Asia dan Afrika dalam buku-buku pelajaran geografi dunia sering memasukkan Islam dan sejarah Muslim. ${ }^{15}$ Ajaran yang tidak otentik atau tidak akurat tentang Islam, pada kenyataannya, bukanlah pendidikan tentang Islam sama sekali. Mungkin pendidikan tentang studi barat Islam, atau pendidikan tentang pandangan penulis buku teks tertentu atau penerbit tentang Islam atau dari apa yang penulis pikir siswa harus diizinkan untuk mengetahuinya. Beberapa buku teks, pada kenyataannya, telah mengambil sikap sekuler tentang agama pada umumnya, menggambarkan agama sebagai fenomena sosiologis murni tanpa menyikapi pandangan praktisi agama tentang wahyu dan kenabian. Dengan kata lain, kebenaran iman secara umum dapat ditempatkan dipertanyakan oleh buku teks karena itu digambarkan hanya sebagai penemuan atau konstruksi manusia.

${ }^{14}$ Douglass, S. L. (2000). Teaching about religion in national and state social studies standards. Fountain Valley, CA : Council on Islamic Education.

${ }^{15}$ Tren keseluruhan menuju peningkatan pengajaran sejarah ditandai dengan meningkatkan peran sumber-sumber primer, meningkatkan kualitas narasi, membuat koneksi geografi lebih sistematis, dan membawa ruang kelas sejarah secara bertahap ke dalam penelitian yang sedang berlangsung selama lima puluh tahun terakhir. Perubahan telah terjadi secara bertahap, namun pada Pendidikan Islam saat ini terlibat dalam penelitian standar lebih lanjut terkait dengan pengajaran tentang dunia dalam sejarah, geografi dan disiplin ilmu sosial lainnya. Studi baru ini diharapkan akan diterbitkan pada tahun 2005. 
Menurut pedoman untuk mengajar tentang agama, sebaliknya, posisi seperti itu sama sekali tidak netral, tetapi mewakili posisi filosofis sekuler tertentu tentang agama. Mengajar tentang agama - apakah Kristen, Yudaisme, Islam, Budha, atau Hindu — harus menggambarkan prinsip dasar iman ketika para penganutnya memahaminya, menggunakan bahasa atributif dalam setiap contoh: orang Kristen percaya bahwa ...; Muslim percaya bahwa ... dll. Selain itu, buku pelajaran sering menggunakan informasi yang tidak akurat atau menghilangkan informasi demi kesederhanaan. Sebagai contoh, kepercayaan pada nabi-nabi Biblika Adam, Nuh, Abraham, Musa dan Yesus adalah prinsip dasar Islam, tetapi buku pelajaran sering menghilangkan informasi ini demi "kesederhanaan" menjadikan Muhammad satu-satunya nabi dan pendiri Islam. Keengganan untuk menyebutkan peran sentral Abraham dalam

Keyakinan Islam merupakan pelanggaran terhadap prinsip ketelitian yang dikaitkan ini, karena tanpa Abraham, keyakinan dan praktik Islam tidak dapat dipahami secara memadai. Secara keseluruhan, bagaimanapun, kepatuhan editor buku teks terhadap prinsip keaslian, keadilan dan keseimbangan telah meningkat selama dekade terakhir ini, menghasilkan akurasi yang lebih besar dalam akun buku teks Islam serta agama lain

\section{PENDIDIKAN TENTANG ISLAM MELALUI MEDIA POPULER, WORLD WIDE WEB, DAN AKADEMISI}

Analisis sistematis televisi korporasi, radio, media cetak dan liputan media elektronik tentang Islam berada di luar cakupan artikel ini, tetapi perlu menyebutkan media sehubungan dengan pendidikan tentang Islam karena sangat berpengaruh dalam membentuk opini publik di Amerika Serikat. Sejak 11 September 2001, serangan tiba-tiba media "versi" Islam, interpretasi ayat-ayat Al-Qur'an tertentu, dan upaya untuk mendefinisikan apa Islam "adalah" atau "seharusnya" telah muncul di berbagai media. Cakupan menjalankan keseluruhan dari penistaan ekstrim Islam dan Muslim untuk cakupan yang seimbang, adil dan menyeluruh Islam sebagai agama, dan umat Islam dalam sejarah dan masyarakat kontemporer.

Di antara media baru adalah situs web yang dikembangkan oleh organisasi, kelompok kepentingan dan individu pribadi. Tidak seperti 
situs "ekumenis" seperti Beliefnet.com, upaya tersebut termasuk situs web yang dirancang untuk mencegah orang dari memeluk Islam, atau untuk mendorong pembentukan sikap negatif tentang Islam dan Muslim, kadang-kadang ke titik kebencian. Pada saat yang sama, umat Islam telah mengembangkan berbagai situs web, beberapa di antaranya dimaksudkan hanya untuk menginformasikan, orang lain untuk menyebarkan Islam dengan mengundang orang lain untuk mempelajarinya, dan yang lain untuk membantah polemik dan tuduhan yang ditujukan pada Islam dan Muslim. Banyak dari situs web ini menyesuaikan pendekatan mereka kepada audiens Barat. Situs-situs lain yang dikelola oleh umat Islam mengungkapkan berbagai wacana internal di kalangan umat Islam, yang mewakili beragam dari apa yang disebut kelompok Muslim "progresif" hingga tradisionalis hingga corong ekstremis. Selama beberapa dekade, dan dengan intensitas yang meningkat sejak spesialis, jurnalis dan tokoh agama telah menghasilkan ratusan buku yang dimaksudkan untuk mendidik masyarakat tentang Islam. Penulis mereka sering muncul di media elektronik sebagai ahli juga. Pentingnya wacana ini - Muslim dan non-Muslim - digarisbawahi oleh volume dan keunggulannya, dan dengan cara di mana idenya beredar di media cetak, melalui gelombang udara, dan di Internet, mengalir dari satu format ke format lainnya. Seperti sebuah wacana tentang agama dunia dan kitab sucinya, kepercayaannya, praktiknya dan pandangan serta tindakan para penganutnya dan para penganutnya, jelas dalam skala yang belum pernah terjadi sebelumnya.

\section{KONSEPSI TEORETIS PENDIDIKAN ISLAM}

Pendidikan dalam semangat Islam adalah kategori terakhir tetapi yang paling penting dalam tipologi ini, karena sering kali ini adalah makna pertama pembaca terhadap frase, pendidikan Islam. Sayangnya, karena pusaran perhatian media terfokus pada pendidikan untuk dan Muslim, istilah ini dapat berkonotasi untuk beberapa orang konsep pendidikan begitu terbatas sehingga menyiratkan bahwa pendidikan Islam menghilangkan pengetahuan sekuler dalam mendukung keyakinan agama, dan mungkin disamakan dengan penyebaran ketidaktahuan. Beberapa orang mungkin menganggap bahwa pendidikan Islam mungkin singkatan untuk mengajarkan kebencian "Barat" atau Amerika Serikat. 
Konsep pendidikan Islam tidak dapat direduksi menjadi stereotip seperti itu, juga tidak terbatas pada transmisi yang kaku dari kehidupan tahun 1400 tahun dari Arab kuno. Pendidikan Islam tentu saja merupakan bagian dari tradisi sejarah, tetapi bukan kebalikan dari modernitas, demokrasi atau nilai-nilai Barat. Selain stereotipe, pandangan Islam dan pembelajaran semacam itu juga dihasilkan dari identifikasi yang berlebihan terhadap ajaran agama semata-mata dengan konteks historis / budaya konflik Gereja / sains yang dikenal dalam tradisi pendidikan Barat, yang secara keliru dianggap universal bagi pengalaman manusia. Paragraf berikut membahas beberapa istilah dan konsep kunci dari terminologi Islam dan Arab yang secara historis dan saat ini terkait dengan pendidikan dalam tradisi Muslim.

Pendidikan adalah tugas pertama seorang Muslim, pria atau wanita. ${ }^{16}$ Pengetahuan tentang Tuhan disamakan dengan proses belajar dan mengajar. Proses melestarikan kitab suci Islam yang didokumentasikan dengan baik menunjukkan awal mula munculnya tradisi melek huruf dan penyebarannya di kalangan Muslim sebagai prioritas sosial. Sudah menjadi kewajiban komunitas Muslim sejak awal untuk melakukan firman Tuhan dan ajaran Muhammad untuk mengenang dan menulis. Di antara pernyataan yang paling sedikit diteliti dalam literatur akademis adalah gagasan bahwa Al Qur'an dikumpulkan dari fragmen setelah kematian Nabi Muhammad SAW. Dari periode paling awal, pembacaan bagian-bagian yang diungkapkan dari Al Qur'an adalah bagian dari kehidupan masyarakat. Karena ayat-ayat itu tidak diungkapkan dalam urutan di mana mereka muncul dalam Al Qur'an yang lengkap, proses yang sedang berlangsung untuk menertibkannya adalah bagian dari misi Muhammad untuk mengirimkan wahyu sampai selesai lebih dari 23 tahun kenabiannya. Ahli-ahli Taurat melakukan pekerjaan meletakkan penduduk Al-Qur'an untuk mengenang banyak pengamat dan secara tertulis. Kata-kata Muhammad sendiri dan perbuatan-perbuatannya

${ }^{16}$ Memang, ayat-ayat pertama Al-Qur'an yang terungkap dalam pertemuan dengan Malaikat Jibril, seperti yang dilaporkan oleh Nabi Muhammad adalah: "Baca! Dalam nama Tuhanmu dan Cherisher, Yang menciptakan; Menciptakan manusia dari segumpal beku darah: Baca! Dan Tuhanmu Yang Maha Pemurah; Dia yang mengajar (menggunakan) Pena; Diajarkan manusia yang tidak dikenalnya. “ (Qur'an 96: 1-5) 
yang patut dicontoh juga dicatat (dalam hadits), dan ilmu-ilmu tafsir Al-Qur'an dan otentikasi serta evaluasi hadis menjadi dasar dari disiplin keilmuan dan hukum Islam.

Pada periode awal Abbasiyah, tradisi melek huruf telah mapan di banyak bidang studi. Menulis sejarah menjadi menonjol untuk merekam peristiwa penting dalam kebangkitan Islam. Sejarah daerah-daerah yang baru mengenal Islam sering berkomitmen untuk menulis untuk pertama kalinya, dan munculnya "sejarah universal" mensintesis banyak yang diterima pengetahuan tentang masa lalu Alkitab, dan peradaban India dan Persia. ${ }^{17}$ Pada saat itu, studi tentang Humaniora bermekarab dengan perkembangan peradaban Muslim. Pengetahuan ilmiah dibangun di atas dasar pengetahuan praktis orang-orang Arab di bidang pelayaran, navigasi dan astronomi, perdagangan, peternakan dan pertanian. Dukungan khalifah Caliphal menyediakan dana dan pengembangan hukum Islam memberikan motivasi bagi para sarjana untuk menetapkan standar tinggi untuk menjaga waktu dan kalender, orientasi yang akurat dari arah ibadah ke Ka'bah, dan perhitungan warisan, berat, dan ukuran. Keingintahuan, akses geografis, dan sarana yang cukup memberikan dinamika untuk terjemahan besar-besaran, penyerapan, pengembangan, dan penyebaran pengetahuan dari semua jenis. ${ }^{18}$ Kedatangan tepat waktu dari teknologi pembuatan kertas dari Cina memberikan dorongan tambahan untuk dinamika ini. ${ }^{19}$ Berkembangnya tradisi melek huruf ini menghasilkan pembentukan lembaga-lembaga pendidikan yang memajukan ide-ide tentang pendidikan Islam jauh melampaui permulaannya yang belum sempurna, dan yang terus membentuk gagasan-gagasan semacam itu hingga saat ini.

Dinamika perolehan pengetahuan dalam peradaban Muslim awal memberikan konsep pendidikan Islam yang tidak menempatkan

${ }^{17}$ Duri, A. A. (1983). The rise of historical writing among the Arabs. L. I. Conrad (Trans.). Princeton: Princeton University Press. And Gibb, H. A. R. (1987). Tarikh. Encyclopedia of Islam. Leiden : E.J. Brill. Education for Life. Available at: http:// www.eliman.org.

${ }^{18}$ Hassan, A. Y. \& Hill, D. (1986). Islamic technology. Cambridge : Cambridge University Press. And Watson, A. (1983). A medium for diffusion. In Agricultural innovation in the early Islamic world. Cambridge : Cambridge University Press.

${ }^{19}$ Bloom, J. M. (2001). Paper before print: The history and impact of paper in the Islamic World. (pp. 91-123). New Haven and London : Yale University Press. 
penghalang antara pembelajaran "agama" dan "sekuler". Islam dalam konteks ini harus dipahami seperti halnya dalam tradisi yang paling beradab dalam sejarah dunia - sebagai cita-cita universal pengetahuan manusia, bukan sebagai kendala. Para sarjana mengidentifikasi disiplin yang merupakan bagian dari seluruh rangkaian pengetahuan yang harus diperoleh oleh orang yang benar-benar terdidik sebelum berspesialisasi dalam disiplin khusus apa pun. Kurangnya penggambaran yang jelas antara pengetahuan duniawi dan spiritual tidak menyiratkan bahwa pengetahuan berdasarkan alasan, pengamatan dan eksperimen dianggap tabu, hanya karena wahyu dianggap sebagai kebenaran terpenting. AlQur'an mendesak orang-orang beriman untuk menggunakan alasan untuk memverifikasi informasi yang disediakan oleh indera, dan pengetahuan berdasarkan wahyu. ${ }^{20}$

Selanjutnya, Al-Qur'an dan hukum Islam mengakui berbagai bidang tindakan manusia seperti bidang aqidah (pasal-pasal kepercayaan), ibadat (bentuk-bentuk ibadah) dan 'ilm (merangkul pengetahuan dari dua yang pertama serta pengetahuan duniawi). Sebuah hadis dengan jelas menyatakan bahwa Muhammad menyarankan para pengikutnya untuk berpikir secara mandiri tentang hal-hal kehidupan sehari-hari dan keterampilan manusia, dan tidak melakukan hal-hal seperti itu dengan meniru teladannya. Dia meminta saran pengikutnya dan mengandalkan pengalaman dan keterampilan mereka. Kedua, Al-Qur'an adalah sumber inspirasi yang kaya untuk banyak bidang pengetahuan, baik untuk nasihatnya untuk memperoleh dan berbagi pengetahuan, dan untuk deskripsi yang sangat menarik tentang fenomena alam. Orang-orang yang beriman diminta dalam Al Qur'an untuk memuliakan Sang Pencipta dengan menerapkan alasan pada informasi yang diserap oleh indera, dan membuat pengetahuan darinya. ${ }^{21}$

${ }^{20}$ Seperti dalam Al Qur'an, 45:13, "Dan Dia telah menundukkan bagimu seperti dari-Nya semua yang ada di langit dan di bumi: lihatlah, itu adalah Tanda-tanda bagi mereka yang mencerminkan." Atau 14:25, "Allah koin serupa [perumpamaan] bagi umat manusia agar dapat tercermin. “

21 "Tuhanlah yang membelah fajar: Dia membuat malam untuk istirahat dan ketenangan dan matahari dan bulan untuk perhitungan waktu: demikianlah penghakiman dan perintah Yang Mahatinggi Yang Mahatahu. Dialah yang membuat bintang-bintang sebagai suar yang dapat membimbing dirimu sendiri dengan bantuan mereka melalui ruang gelap darat dan laut: Kami merinci Tanda-tanda 
Kata Arab untuk "agama" (din) sendiri memiliki hubungan yang kuat dengan kehidupan intelektual dan beradab, dan dapat dibandingkan dengan konsep serupa dalam warisan intelektual Barat. Dien tidak merujuk pada institusi manusia, tetapi pada kondisi keberadaan (Islam disebut “din.”). Investigasi konsep ini mengarah ke akar bahasa Arab d-i-n, yang maknanya menggarisbawahi hubungan antara spiritual, intelektual, dan kehidupan beradab. Empat makna utama akar adalah: kewajiban timbal balik, penyerahan atau pengakuan, otoritas peradilan, dan kecenderungan alami. Dien mengungkapkan gagasan kewajiban terhadap satu Tuhan, berdasarkan kecenderungan alami terhadap Sang Pencipta. Akar d-i-n juga berkonotasi dengan gagasan hutang atau hutang, transaksi yang melibatkan pertukaran kepercayaan dan kewajiban. Kata untuk kota - madinah - yang berhubungan dengan civitas Yunani, berasal dari akar yang sama. Kota adalah komunitas hubungan sosial yang kompleks dan transaksi yang didasarkan pada pemenuhan kewajiban dan tanggung jawab timbal balik, yang tunduk pada penilaian dan otoritas sipil. Gagasan "peradaban" (lagi-lagi sejajar dengan civitas) juga dikaitkan dengan d-y-n; kata kerja tamaddana berarti menemukan kota, atau untuk memanusiakan pemikiran, dan tamaddun berarti "peradaban" atau "perbaikan masyarakat." Dengan demikian, agama dan pendidikan disatukan dalam usaha manusia untuk mengetahui dan memuliakan Sang Pencipta, dan mencari pengetahuan dan memanfaatkannya secara bermanfaat dalam masyarakat. Pengetahuan ini dikembangkan dan ditransmisikan untuk memastikan keberlanjutan masyarakat yang beradab. ${ }^{22}$

Konsep pengetahuan dalam tradisi Islam, dan istilah bagi mereka yang mengembangkan dan mentransmisikannya, digabungkan dalam akar bahasa Arab 'alm, yang membentuk kata untuk pengetahuan -' ilm, dan partisip yang menunjuk orang yang belajar - 'alim (ulama'). Tradisi keilmuan Islam tidak termasuk penahbisan, tetapi menganugerahkan status sarjana kepada mereka yang penilaian atau pengetahuannya dianggap layak. 'Ulama' telah membentuk kelompok sosial yang sangat

Kami untuk orang-orang yang memiliki pengetahuan. " (Qur'an 6: 96-97

${ }^{22}$ Cornell, V. J. (2002). Religion and philosophy. In S. L. Douglass (Ed.), World eras: Rise and spread of Islam, 622-1500 CE. (pp. 335-336). Farmington Hills, MI : Gale Group. 
berpengaruh sepanjang sejarah peradaban Muslim, dalam peran mereka sebagai pendidik, ahli hukum dan sarjana. 'Ulama' diberi penghormatan dan otoritas yang sering memeriksa kekuatan negara yang terlalu kuat, dan bertindak sebagai hakim dan wali dari yayasan amal. Penyebaran pengetahuan melalui kelas orang lokal dan transregional ini merupakan faktor penting dalam penyatuan keyakinan dan praktik Islam dan dalam mempertahankan tradisi melek huruf dalam Masyarakat Muslim. ${ }^{23}$ Dua konsep tambahan dari budaya Muslim dan bahasa Arab menerangi aspek sosial pendidikan Islam. Salah satunya adalah adab, yang berarti kebiasaan atau norma perilaku yang diturunkan dari generasi ke generasi. Seiring dengan berkembangnya peradaban Muslim, kata itu muncul pada pengertian "kualitas jiwa yang tinggi, pendidikan yang baik, urbanitas dan kesopanan," dua kata terakhir mengacu pada perilaku yang digunakan dalam perusahaan elit, dan perilaku yang sesuai dengan orang yang beradab. Pada masa Abbasiyah, adab akan diperoleh sebagai hasil pendidikan yang bernilai: "kata itu setara dengan urbanitas Latin, kesopanan, kesopanan, penyempurnaan kota". ${ }^{24}$ Konsep tersebut digabungkan ke dalam sistem pendidikan, di mana adab memperoleh makna intelektual: jumlah pengetahuan yang membuat seseorang sopan dan "sopan" dalam budaya sekuler. Untuk menjadi mu'addab, seseorang harus mempelajari ilmu retorika, tata bahasa, leksikografi, metrik, dan fasih dalam puisi, sastra, dan sains. Konsep adab mendukung penyempurnaan estetika kehidupan beradab, dan merupakan bagian integral dari pendidikan dalam semangat Islam

Konsep tarbiyah yang lebih menyeluruh mengacu pada pendidikan moral, dari kata dasar yang terkait dengan akumulasi. Memperoleh pengetahuan, etika, dan pandangan dunia moral adalah fondasi untuk mencapai apa yang dituntut Al-Qur'an dari setiap manusia - untuk memerintahkan apa yang baik, dan mencegah apa yang jahat. Menurut sebuah hadits terkenal dalam koleksi Nawawi (1976), ini dapat dicapai dengan tangan, suara, atau hati. Dengan kata lain, untuk bekerja demi keadilan sosial, seseorang harus mendapatkan alat untuk tindakan yang

${ }^{23}$ Bulliet R. W. (1994). Islam: The view from the edge. New York : Columbia University Press.

${ }^{24}$ Gabrieli, F. (1999). Adab. The Encyclopaedia of Islam, volume 1. [CD-ROM] Leiden : Koninklijke Brill NV. 
benar juga. $^{25}$

Kerangka moral bagi seorang Muslim adalah niat baik, dan untuk memastikan bahwa cara-cara untuk mencapai kebaikan atau menghindari kejahatan ada dalam diri mereka sendiri baik dan bukan sarana jahat. Pendidikan memberi seseorang pengetahuan untuk mengenali tugas, fondasi moral untuk mengetahui apa yang harus dilakukan, dan sumber daya pribadi untuk melaksanakan tugas. Orang-orang yang berpendidikan Islam akan menggabungkan aspek-aspek pendidikan Islam yang dijelaskan di atas. Mereka akan fasih dalam sumber-sumber asli Qur'an dan Sunnah, serta disiplin ilmu Islam yang menyediakan alat untuk belajar. Dalam belajar tentang din, mereka akan belajar untuk melaksanakan tugastugas iman, dan bertindak sesuai dengan prinsip-prinsipnya. Melalui pengajaran etika dan moral, orang yang berpendidikan akan bertindak dengan cara yang bertanggung jawab secara sosial, memperoleh rahmat sosial dari kehidupan yang beradab, dan akan mengambil bagian dan berkontribusi pada jumlah keterampilan dan pengetahuan sesuai dengan waktu mereka. Pernyataan misi dari satu sekolah Muslim di Amerika Serikat mengekspresikan tujuan pendidikan harmonis dan pengabadian iman dan nilai-nilai komunitas ini: Kami memberikan pendidikan yang membangun kecintaan belajar bersama dengan keterampilan akademik untuk melanjutkan pendidikan anak seumur hidup. Kami mendukung pembentukan karakter Muslim dengan membantu siswa mencapai tujuan spiritual melalui pengejaran pengetahuan dan layanan kepada komunitas dan masyarakat. Kami berusaha untuk menumbuhkan perilaku yang mencerminkan moral dan nilai-nilai Islam sebagaimana ditentukan oleh Al-Qur'an dan Sunnah. Kami menumbuhkan semangat penyelidikan yang terbuka di mana iman dan akal mengarah ke pengetahuan yang lebih tinggi, pilihan hidup yang sehat dan kewarganegaraan yang bertanggung jawab.

Kemampuan orang yang berpendidikan, beradab untuk memberi manfaat bagi kemanusiaan, serta kemampuan mereka untuk berkomunikasi dengan orang lain, adalah tujuan pembelajaran yang menciptakan pemahaman dan berbagi nilai-nilai ini dalam percakapan sipil. Tujuannya adalah untuk terlibat dalam upaya kolaboratif untuk memecahkan

${ }^{25}$ Ibrahim, E., \& Johnson-Davies, D. (Trans.) (1976). An-Nawawi's forty hadith. (pp. 110-111). Beirut : Dar al-Koran al-Kareem. 
masalah bersama dan untuk menciptakan masyarakat yang beradab yang berbagi pengetahuan untuk kepentingan semua.

\section{KESIMPULAN}

Jelaslah bahwa kewajiban untuk dididik, dan konsep-konsep moral, intelektual dan budaya dari pendidikan dalam tradisi Muslim tidak jauh dari tujuan dan konsep yang sama yang terkait dengan tradisi dan aspek pendidikan Barat. Beberapa sarjana telah menghasilkan studi akademis yang diperluas mengenai hubungan historis yang diketahui di antara tradisi-tradisi ini, dan dapat melacak garis jelas transmisi nilai dan metode pendidikan yang mengalir ke peradaban Muslim dari tradisi klasik, dan dari peradaban Muslim ke peradaban Barat dari abad ke-11. seterusnya. ${ }^{26}$ Dua pemahaman budaya telah mengambil warisan intelektual yang sama - monoteistik. Tradisi standar moral dan etika, warisan Yunani yang kaya dan kompleks (sebanyak "dari” Timur sebagai "dari” Barat) dan panci perpaduan ide dan disiplin Mediterania, yang juga mengandung pengaruh dari Asia dan Afrika.

Tulisan ini dimulai dengan memperingatkan bahwa istilah, Islam, dalam wacana publik sering memisahkan dan mengasingkan konsepkonsep seperti pendidikan dari asosiasi budaya apa pun yang akan akrab bagi pembaca atau pendengar Amerika yang berpendidikan Barat. Diharapkan bahwa tingkat keakraban konseptual dan institusional telah dibangun yang dapat menjembatani antara ide-ide pendidikan dan institusi yang saat ini ada di area yang dilindungi undang-undang ruang publik Amerika, termasuk yang berkembang di komunitas Muslim Amerika.

${ }^{26}$ LeGoff, J. (1993). Intellectuals in the Middle Ages. Cambridge : Blackwell. And Makdisi, G. (1981). The rise of colleges: Institutions of higher learning in Islam and the West. Edinburgh : Edinburgh University Press. 


\section{REFERENSI}

Al-Qur'anul Karim

Bagby, I., Perl, P., \& Froehle, B. (2001). The mosque in America : A national portrait. Washington, DC : Council on American-Islamic Relations. Haddad, Y. (1997, March). Islam in the United States : A tentative ascent; A conversation. U.S. Society and Values: The religious landscape of the United States. Khalidi, O. (2000). Mosque. In W. C. Roof (Ed.), Contemporary American religion. New York : Macmillan.

Bloom, J. M. (2001). Paper before print: The history and impact of paper in the Islamic World. (pp. 91-123). New Haven and London : Yale University Press.

Bulliet R. W. (1994). Islam: The view from the edge. New York : Columbia University Press.

Cornell, V. J. (2002). Religion and philosophy. In S. L. Douglass (Ed.), World eras: Rise and spread of Islam, 622-1500 CE. (pp. 335-336). Farmington Hills, MI : Gale Group.

Douglass, S. L. \& Dunn, R. E. (2001). Interpreting Islam in American schools. In H. Donnan (Ed.), Interpreting Islam. London : Sage Publications. Hal. 76-98

Douglass, S. L. (1998, Winter). God spoke: Guidelines and coverage of Abrahamic religions in world history textbooks. Religion and Education, 25 ( $1 / 2)$, 45-58.

Douglass, S. L. (2000). Teaching about religion in national and state social studies standards. Fountain Valley, CA : Council on Islamic Education.

Douglass, S. L. (2000). Teaching about religion in national and state social studies standards. Fountain Valley, CA : Council on Islamic Education.

Duri, A. A. (1983). The rise of historical writing among the Arabs. L. I. Conrad (Trans.). Princeton: Princeton University Press. And Gibb, H. A. R. (1987). Tarikh. Encyclopedia of Islam. Leiden : E.J. Brill. Education for Life. Available at: http:// www.eliman.org. 
Gabrieli, F. (1999). Adab. The Encyclopaedia of Islam, volume 1. [CDROMł Leiden : Koninklijke Brill NV.

Hassan, A. Y. \& Hill, D. (1986). Islamic technology. Cambridge : Cambridge University Press. And Watson, A. (1983). A medium for diffusion. In Agricultural innovation in the early Islamic world. Cambridge : Cambridge University Press.

Haynes, C. C. \& Thomas, O. (2002). Finding common ground: A guide to religious liberty in public Schools. Nashville, TN : First Amendment Center.

Ibrahim, E., \& Johnson-Davies, D. (Trans.) (1976). An-Nawawi's forty hadith. (pp. 110-111). Beirut : Dar al-Koran al-Kareem.

Ismail, M. (n.d.). Teaching tips and effective strategies for weekend Islamic schools. Indianapolis, IN: American Trust Publications. Islamic Schools League. Available at: http://www.4islamicschools. org. (2003)

LeGoff, J. (1993). Intellectuals in the Middle Ages. Cambridge : Blackwell. And Makdisi, G. (1981). The rise of colleges: Institutions of higher learning in Islam and the West. Edinburgh : Edinburgh University Press.

Muslim Home School Network and Resource. Available at: http://www. muslimhomeschool.com/index.html, 2004

Safi, L. (1999). The transforming experience of American Muslims: Islamic education and political maturation. Available at: http://home.att. net/ louaysafi/articles/1999/am-muslims.html. Tauhidi, Daud. The Tarbiyah Project: An Overview. Daud Tauhidi, 2001. 